\title{
Positioning as Normative Actors - China and the EU in Climate Change Negotiations
}

\begin{abstract}
This article focuses on the communication tools employed by the European Union (EU) and the People's Republic of China (PRC) to project themselves as normative actors and their construction of specific role conceptions in the context of global climate change negotiations. The empirical spine of the article consists of a discourse analysis of 134 documents released by the EU and China on the issue of climate change and climate change negotiations between the 2008 Copenhagen and the 2015 Paris Climate Summits. The findings reveal that both the EU and China go to great lengths to position themselves as 'responsible global citizens', employing relatively consistent framing devices. Not only are the findings interesting when it comes to identity-building of the EU and China as foreign policy actors, they also hint at more generic parameters along which the role 'normative actor' is constructed.
\end{abstract}

\section{Key Words:}

EU, China, Normative Actor, Climate Change Negotiations

\section{Introduction ${ }^{1}$}

This article examines how the EU and China position themselves as normative foreign policy actors in the context of climate change negotiations. It employs a broad constructivist approach emphasising recognition and context in identity formation. This article contributes to literature on normative actorness by analysing how the recognition and perception as a normative foreign policy actor are generated and re-enforced through the application of particular communication strategies and devices in press releases and other official documents.

\footnotetext{
${ }^{1}$ I would like to use this opportunity to thank Dr Warrier and the two anonymous JCMS reviewers for their helpful comments on earlier versions of this article.
} 
The article maintains that the EU and China use climate change negotiations to position themselves as normative foreign policy actors. Both have emerged as effective co-leaders of the UNFCCC (United Nations Framework Convention on Climate Change) process, with the EU representing developed countries and China representing the interests of less-developed countries. The EU has long regarded itself as a vehicle for the global promotion of good governance principles, democracy, environmental protection, poverty alleviation and human rights and has a well-established reputation as a protagonist for climate change management (Bretherton \& Vogler, 2006). China is a relatively new power in the context of global governance. Its growing capabilities have enabled it to take a much more proactive approach, extending its influence in multilateral structures (Chin, 2010). This has generated concerns about the implications of a rising China (Mearsheimer, 2006). These fears appear to be substantiated with Beijing's position on long-running territorial disputes such as in the South China Sea or the Senkaku islands. There are also suspicions regarding the motivations behind Xi Jinping's Belt and Road Initiative which is regarded by some as a strategic attempt to enhance Chinese dominance. Similarly, China has become much more confident in putting forward its own interpretation of universal values, as seen in its defence of internment camps in Xinjiang. To counter suspicions, Chinese discourses have continuously stressed the peaceful rise of the PRC, working towards harmonious development (Mohanty, 2013). Framing itself as a normative foreign policy actor providing public goods in the form of a sustainable global climate change management regime supports the image of China as a responsible rising power.

Normative foreign policy actors need to be seen to be looking beyond narrowly conceived self-interest and providing collective goods. Climate change negotiations offer the perfect arena for aspiring normative foreign policy actors to project themselves as responsible global citizens. Climate change is an urgent and immediate issue. The linkages between climate 
change, economic development, energy and food security and the amplified risk of conflict and social instability make finding effective long-term solutions a salient foreign policy issue for most countries, necessitating effective global governance responses.

The first part of the paper introduces the normative foreign policy actor concept and links to positioning and framing analysis. The subsequent empirical part rests on a framing analysis of 134 press releases and official statements by the EU and China to identify recurring frames employed by the EU and China to construct images of themselves as normative actors within the context of global climate change negotiations.

\section{Theoretical Framework and Methodology Identity and Normative Foreign Policy Actors}

Dûchene (1972), Galtung (1973) and Bull (1982) developed the earliest conceptualisations of the European Community's role in the world. These offer the background for the idea of 'normative power' Europe (NPE), first defined by Ian Manners (2002), where Manners further developed Dûchene's notion of 'civilian power' to describe the EU's commitment to global moral causes. The NPE concept claims the EU's external relations are influenced by a set of normative principles and shared beliefs that are at the core of the EU's selfunderstanding. These norms and principles are codified in various places in the acquis commauntaire, for example, in the so-called Copenhagen criteria, in EU development and assistance policy. They were also incorporated in the 2009 Lisbon Treaty (Article 21) of the amended Treaty on European Union. Broadly speaking, the NPE argument asserts that the EU's relations with the rest of the world are shaped to advance 'democracy, the rule of law, the universality and indivisibility of human rights and fundamental freedoms, respect for human dignity, the principles of equality and solidarity, and respect for the principles of the United Nations Charter and international law' (TEU, 2012). 
This is a direct extension of the internal legal, contractual and rule-based governance mechanisms that characterise the EU policy-making environment (Lavenex, 2004). The EU's self-understanding, therefore, has significant implications for the external persona the EU aims to project (Manners, 2006, pp. 81-82). The EU regards itself as a source of peace and stability for its member-states -- a security community built on a strong supranational institutional and legal framework. This self-image permeates every aspect of the EU's external relations and has become part of the foreign policy identity of the EU (Manners, 2002; Manners, 2010; Manners \& Whitman, 2003). The EU aims to diffuse its own model, thereby 'normalising' its own legal rules-based approach to global governance (Tocci, 2008, p. 3). NPE adds an ethical dimension to EU foreign policy --indeed, some authors have argued that normative power Europe is related to the wider attempt to construct a European identity in the post-Cold War world (Diez, 2005). In a world dominated by states, the EU aims to establish itself by differentiation, i.e. as a different kind of 'power' and a 'force for collective good'. This is done through the promotion of universal values, shared interests and the powers of attraction and persuasion (Manners 2002).

The NPE concepts regards the EU as fundamentally different from other actors in its goals and instruments, relying on the attractiveness of its own model rather than on coercion (see Manners 2002). However, it is also possible to argue that NPE reflects a lack of capabilities. In strategic terms, the EU tends to rely heavily on NATO and the US (Tocci, 2008, p. 3). Furthermore, being a normative foreign policy actor (NFPA) may not be as unique as claimed by NPE. All states employ normative justifications for their activities (Kavalski, 2014, p. 304). Indeed, several studies have demonstrated that normative power can also be associated with the US and rising powers such as China, India, and Russia (Kavalski, 2007; 2013; 2014; Tocci, 2008) and regional organisations such as the Association of Southeast Asian Nations ASEAN (Stubbs, 2008). 
China, as a major rising power, is of interest here. Together with the EU, China has effectively emerged as co-leader of the UNFCCC process. As a foreign policy actor, China simultaneously takes on the identity of a developing country, an emerging economy and a great power (Breslin, 2013, p. 617). At the core of China's normative priorities is the emphasis on a communitarian notion of sovereignty: each country ought to develop its own political and economic system and norms without undue outside interference. This insistence on a Westphalian reading of sovereignty premised on non-interference ultimately represents the core of China's external identity - an alternative normative power to the West (and the EU). It forms part of Zhou Enlai's Five Principles of Peaceful Coexistence (Womack, 2008, p. 266; Breslin, 2013, p. 631) and of China's international positioning as a NFPA, thereby also providing an antidote to the China-threat image.

It follows that NPE is a specific expression of a more general NFPA concept. Being a NFPA is a cognitive category based on perceptions. Such perceptions are the result of images which characterise the 'total cognitive, affective and evaluative structure of the behavioral unit, or its internal view of itself and its universe' (Boulding, 1956, p. 423). NFPA is an image, a specific representation of the self (Diez \& Pace, 2007), constructed discursively. It is relational, contextual and dynamic, pointing to the 'other' in identity construction. The relations between the self, the other and context has been explored by Duveen who argues that actors are able to assume various possible identities by positioning themselves in different ways in relation to specific issues (Duveen, 1993). Context and recognition are crucial components of the normative actor image. Indeed, Kavalski (2013, p. 258) makes recognition a core condition not only for interaction but also for identification as a capable and relevant actor in a specific context. Thus, the framing and positioning of an entity as a normative and responsible actor in international relations links principles, actions and impact. For external recognition, the principles underpinning NFPA ought to be perceived as 
legitimate, actions ought to be persuasive and impact will be generated through deliberative interactive relations and the socialisation of others (see Kavalski 2013, p. 260). Recognition as a NFPA is tied to legitimacy and this legitimacy must be 'earned' (Kavalski, 2014). The positioning of actors becomes evident in their use of specific communication frames to construct recognition and legitimacy.

\section{Methods - Positioning and Framing Analysis}

This article employs positional framing to analyse how the EU and China (i.e. 'existing objects') are framed as NFPA in the context of global climate change negotiations. $^{2}$ Positioning and framing are theoretical frameworks investigating how people construct the social world through interactive processes (Gordon, 2015, p. 326) Positioning can be defined as a process whereby identities or 'selves' are located within, and expressed through, conversational practices (Davis \& Harré, 1990; Andreouli, 2010). Framing helps us to understand how this is being done. It describes how actors draw on communication resources to construct and disseminate meaning (Saarikoski, 2006, p. 617). Positional framing, therefore, refers to a deliberate communication strategy. Position is sometimes used as a synonym for role or identity (i.e. actorness) (Davis \& Harré, 1990; Harré \& Van Langenhove, 1999). Positions locate actors within a specific context and in relation to the 'other'. Moreover, every position has a moral quality that delineates a set of rights and duties (Andreouli, 2010, pp. 5,6).

Framing is designed to activate certain schemata among an audience by 'selecting and highlighting some facets of events or issues and making connections among them so as to promote a particular interpretation, evaluation and/ or solution' (Entman, 2004, p. 5).

\footnotetext{
${ }^{2}$ They can be successfully interwoven (Gordon, 2015, p. 338).
} 
Framing is a process of mapping social reality to influence how people define particular situations (Gordon, 2015, p. 324). It manifests itself in speeches, press releases and media statements through word choice, the use of certain metaphors, arguments and emotive language (Van Gorp, 2007, p. 64). These devices are held together by a central organising theme - the frame. Frames are tools employed to decide which elements of reality should be focused on by an audience (Van Gorp \& Vercruysse, 2012, p. 1275). They can be understood as lenses that magnify certain aspects of a story, providing an audience with guidelines for interpreting a story. This is important, since any issue can be viewed from a variety of perspectives, generating different interpretations and implications (Chong \& Druckman, 2007, p. 104). When actors frame a message, they connect an issue to preconceptions within a given culture such as values, archetypes and shared narratives (Van Gorp \& Vercruysse, 2012, p. 1275). Thus, frames are employed to filter and channel perception of a specific issue and a subject. They act to define a problem, allow for moral judgements whilst also offering solutions.

Framing analysis is considered by some as a sub-set of discourse analysis. However, while there are certain similarities, there are also significant differences:

[...] where discourse analysis looks at how an interrelated set of texts, and the practices of their production, dissemination, and reception bring an object into being, frame analysis looks at how existing 'objects' or 'topics' are framed by different actors, bending their meaning in certain directions (Lindekilde, 2014, p. 200).

Political elites spend a considerable amount of time determining frames to channel public perception of an issue in a specific direction. This makes framing analysis a useful tool to discover and underline the central organising ideas and story lines on NFPA. Here, we examine how these are employed by the EU and China in climate change negotiations. We 
can derive a framework for exploring how the NFPA image is constructed in three related steps: an actor evaluates an issue, takes position(s) and locates itself in relation to other actors. Hence, we are looking for frames relating to moral evaluation, locating the self and alignment with others.

The paper uses an inductive approach to retrieve frames through thorough interpretation of documents in connection to climate change. It applies a qualitative methodology to enable us to locate frames with their specific context. Quantitative methods and machine coding tend to rely on pre-identified frames and remove context and the finer nuances from the corpus.

\section{Samples}

The dataset is composed of formal press releases, white papers, speeches and memos by EU and Chinese official regarding climate change between 1 January 2008 and 31 June 2016, i.e. from United Nations Climate Change Conferences in Copenhagen to Paris (and its immediate aftermath). ${ }^{3}$ The samples have been drawn from the EU's RAPID database and the China Climate Change Info-Net. RAPID is the EU press release database. China Climate Change Info-Net (CCCHINA) focuses on China's efforts to address climate change and related problems. It contains press releases and official position papers and is directed at an Englishspeaking audience. In order to systematise the data collection as far as possible, both repositories where searched for texts referring to climate change. This generated an extremely large number of results, especially from RAPID. To delineate relevant documents from those that are not primarily concerned with climate change but use the term in a different context all texts where examined further manually. This reduced the sample size to 99 on the EU side

\footnotetext{
${ }^{3}$ The Copenhagen summit was supposed to articulate a new climate action framework to replace the Kyoto Protocol. However, it failed with developed and developing countries blaming each other.
} 
and 35 for China. Each text was coded with the aim of identifying the specific way in which climate change is being discussed, including recurring metaphors, catch phrases and arguments indicating how the challenges posed by climate are being framed, and the positions taken by the EU and China regarding climate change. The coding followed an inductive process and did not assume any specific frames in advance. In all, nine frames were detected:

- F1 - Evaluation: Urgent Issue Frame, Vulnerability Frame

- F2 - Positioning as responsible actor: Responsibility Frame, Partner and Advocate of the Global South Frame

- F3 - Positioning as leading by example: Positive Example Frame, Evidence Frame

- F4 - Relationship to others: Negative Othering Frame, Positive Othering Frame, Differentiated Responsibility Frame

It must be emphasised that the analysed samples are not exhaustive. They do by no means cover the full range of public material released by both actors between 2008 and 2016 - or indeed since then. There is also an imbalance between Chinese and EU sources. ${ }^{4}$ However, the results enable us to form a tentative picture of the frames employed by the EU and China to construct the NFPA image in the context of climate change negotiations.

Although the article is treating the EU and China as single personas, this should not detract from the complexity of composite actors in international relations. Neither the EU nor a state such as China possesses agency in the strict sense. The complexities of EU foreign policy are well rehearsed in the literature. China too is hardly a coherent or unitary actor but masks beneath the surface a range of actors involved in international activities, including different ministries, government agencies, major enterprises and policy bank, even local government

\footnotetext{
${ }^{4}$ This is due to the availability of sources from RAPID and CCHINA rather than a selection bias.
} 
all with their own agendas and objectives (Breslin, 2013, p. 618). Thus, like the EU, as foreign policy actor China can suffer from cohesion and consistency problems. The press releases and statements by the relevant EU and Chinese institutions, ambassadors and officials are regarded as the 'voice' of the EU and China for pragmatic reasons only. After all, they tend to create and enhance an image of the EU and China as coherent actors.

\section{Analysis}

\section{F1 - Evaluation}

The moral evaluation of an issue plays an important role in the construction of the 'self'. Based on specific evaluations, positions can be legitimised and delegitimised. The evaluation of climate change is frequently present in the analysed sources (78 out of the 134 documents) with terms that include risk, threat or crisis. Both, the EU and China, employ moral metaphors and scientific storylines in evaluating climate change and justifying their own position on the issue. The overwhelmingly dominant frame is the Urgent Issue Frame. The central organising idea here is an evaluation of climate change as a critical multidimensional risk. This evaluation of climate change as a threat legitimises immediate collective action. Phrases such as major global issue, decisive global challenge, costly consequences, wake-up call or irreversible threat are frequently used to underline the urgency of the issue. This is done by both actors, China and the EU. For example, in a speech at a high level conference on climate change in Beijing, Wen Jiabao defined climate change as 'a major global issue' (Jiabao, 2008). This is echoed an EU-Africa ministerial statement which frames climate change as a:

[...] decisive global challenge, which, if not urgently addressed not only the environment and the ecosystems on which we all depend but also the world economic prosperity, development, food security and, more broadly, stability and security [...] climate change represents an urgent and 
potentially irreversible threat to human societies and the planet, and thus requires to be urgently addressed' (EC, 2014c).

Scientific evidence is used by both sides in legitimising climate change as a threat. A key example can be found in a US-China joint statement on climate change which points to an 'overwhelming scientific consensus about anthropogenic climate change and its worsening impacts, including the sharp rise in global average temperatures over the past century, the alarming acidification of our oceans, the rapid loss of Arctic sea ice, and the striking incidence of extreme weather events occurring all over the world' (CCChina, 2013). The Urgent Issue Frame makes action on climate change a requirement for a NFPA.

The second key frame employed by the EU and China to evaluate climate change as a moral issue is the Vulnerability Frame. This sets out a clear moral obligation to help developing countries in mitigating the challenges posed by climate change. A European Commission memo on Pacific islands-EU relations is typical for the way this frame is employed. It stresses the devasting implications of climate change on the 'already fragile situations' faced by many developing countries, threating to undermine 'progress towards Millennium Development Goals' (EC, 2012). This frame is employed more frequently by the EU than by China to legitimise aid and assistance measures, although, as we will see later, China is positioning itself as a leading developing country.

Both frames (Urgent Issue and Vulnerability Frame) are employed to connect to existing narratives, activating specific images among the audience such as, for example, the transnational nature of climate change and the associated collective moral implications of (in)action. This links to well-established external discourses (e.g. from the scientific community). Thus, they promote a particular evaluation supporting specific solutions but also channel expectations of acceptable behaviour. 


\section{F2 - Positioning as Responsible Actor}

The positioning of the 'self' in relation to the moral evaluation of a specific context is an important step in identity construction. Within the context of NFPA, the 'self' is being constructed as an active provider of collective goods, going beyond narrow self-interest. Barroso's speech at the plenary to the 2009 Copenhagen conference is a key example how this frame is employed. Here, Barroso emphatically urged that parties involved in climate change negotiations

\footnotetext{
'should not be seen making the traditional diplomatic negotiations but fighting for the same common good: life on our planet, life for future generations ... these negotiations are a test for global responsibility and global solidarity’ (EC, 2009).
}

Two frames are being used in this context. The Responsibility Frame is the most frequently employed frame. It has been found 286 times in 95 of the sources. Here, the NFPA image is supported by positioning the EU and China as proactive global citizens, offering solutions and shaping the agenda of international environmental negotiations (diplomatic leadership). It is derived from the moral imperative of the evaluation of climate change in the way outlined above. What this exactly entails, however, differs for the two actors. For the EU, the emphasis is on strong international institutions and legally binding commitments. This is a direct reflection of the EU's internal formal and legalistic institutional framework. Global efforts, international cooperation, a legally binding global framework and multilateralism are defining and reoccurring themes. This is, for example, displayed in a Commission press release prior to the 2011 Durban climate summit which emphasised the desire for a 'a roadmap and deadline for finalising an ambitious, comprehensive and legally binding global 
framework for climate action by all major economies' (EC, 2011). This remained a theme in the 2015 Paris Accords. In the months leading up to the Summit, Commissioner Miguel Arias Cañete stated that 'the Paris Agreement must be internationally legally binding and applicable to all' (EC, 2015a). Within this frame, diplomatic leadership is being established via recurring appeals to ambitious and concrete targets, encouraging legally binding solutions. In this way, the EU is systematically constructed as an agenda setter for global climate action. At the 2009 Copenhagen climate change conference, for example, the EU expressed its goal as making 'as much progress as possible in Copenhagen towards a full treaty and to reach an ambitious and comprehensive political agreement covering all its key elements' (EC, 2009).

China uses a different variation of the Responsibility frame to position itself as NFPA, framing itself as a developing country facing multiple challenges. This is displayed in $\mathrm{Hu}$ Jintao's remarks at a major economies meeting on climate change in 2008:

It [China] faces an imbalance in terms of development between the urban and rural areas, among different regions, and between the economic sector and the social sector, and people's living standard is still not high. China's central task is now to develop the economy and make life better for the people (Jintao, 2008).

As a developing country, China has a special responsibility to ensure the welfare of its citizens. Despite this, however, China has 'adopted a highly responsible attitude' on the issue of climate change (Zhe, 2009). This is reaffirmed by several statements and documents outlining the actions China has taken to address climate change (Zhenhua, 2008a; SCPRC, 2011). Documents such as the 2015 US-China Joint Presidential Statement on Climate Change employ this frame by highlighting China's efforts 'to advance ecological civilization and promote green, low-carbon, climate resilient and sustainable development through 
accelerating institutional innovation and enhancing policies and actions' (CCCHINA, 2015b).

China's actions on climate change also include working with multilateral institutions at the global and regional level as well as engaging bilaterally with developed and developing countries. These activities are regularly published by the National Development Reform Commission.

A second frame supporting the positioning as a responsible actor is the Partner and Advocate of the Global South Frame. This is employed 110 times in 57 of the analysed sources. China, by stressing its own identity as a developing country, is adopting a decidedly Global South perspective in climate change negotiations. Indeed, it positions itself as a leading advocate for the Global South by consistently pushing for the transfer of climate-friendly technologies from developed countries to the Global South and for the provision of financial support to enable developing countries to achieve their economic goals and to adapt to the challenges posed by climate change (Ping, 2008). The UN Millennium Goals and the basic needs of developing countries must be given full consideration (Jintao, 2009). This frame is also evoked by Wen Jiabao in a speech on Technology Development and Technology Transfer:

\footnotetext{
The current climate change is mainly caused by the accumulated emission by the developed countries over many years. Developing countries, especially the least developed ones are weak in climate change adaptation, thus it is unfair that they have to bear its serious consequences. ... developed countries should ... face up to the reality of their high per capita emission ... and effectively honour their commitments under the Bali Roadmap to provide developing countries with support in financing, technology, and capacity building to cope with climate change (Jiabao, 2008).
}

Furthermore, China characterises itself as actively promoting South-South cooperation to address climate change (NRDC, 2015, p. 57). Historical responsibilities, technology transfer, 
financial support and per capita emissions are key metaphors designed to evoke this specific frame.

The EU too is consistently positioning itself as a partner and advocate of developing countries in adapting to climate change. Responsibility, moral obligation and sustainable development are key terms here. The EU is legitimising itself by repeatedly stressing its provision of development aid and assistance packages. Climate finance for developing countries has steadily increased, enabling those countries to adapt to the threats arising out of climate change (EC, 2015b). This is supported by a consistent use of evidence frames discussed in the next section.

\section{F3 - Positioning as Leading by Example}

This frame category is routinely employed (203 times in 93 of the analysed sources) to legitimise the positioning of the 'self' as a responsible actor. The Positive Example Frame offers a causal chain of 'leading by example' reasoning devices, providing directional leadership and offering solutions to collective action problems (Parker \& Karlsson, 2010, p. 927). It endorses an understanding of the NFPA concept by providing specific examples of achievements or measures depicted as best practice. Previous research has indicated that the EU aims to construct itself as a responsible and progressive power with respect to climate change by implementing high environmental policy standards internally and by shaping the evolving global environmental governance structure externally (Bretherton \& Vogler, 2006). The EU thus seems to aspire to become and to be recognised as 'a global leader in international environmental politics' (Kelemen, 2010, p. 335). This is confirmed by the sources where the EU routinely portrays itself as pioneer and trailblazer, hoping that others will follow in an 'equally ambitious and determined manner' (EC, 2014d). It is doing so by pointing at its own internal norms, legal mechanisms, targets and standards. Hence, it can be 
argued that the EU is constructing its legitimacy as responsible actor by providing directional leadership through setting a positive example. In the EU documents we find, for example, references to Europe's 2020 target to unilaterally cut emissions to $20 \%$ below 1990s levels (EC, 2009). Indeed, the EU is willing to 'scale up this reduction to $30 \%$ if other major economies agree to do their fair share' (Hedegaard, 2010a). The EU Emission Trading Scheme (ETS) occupies a key position in these narratives of best practice. It is presented as a tool helping the EU to tackle climate change in a cost-effective way, enhancing efficiency and competitiveness and stressing the compatibility between environmental and economic goals. During a speech at the 2014 UN Climate Summit in New York, Barroso made it quite clear that the EU is a leader in addressing climate change:

In 2005, we created the world's first and largest carbon market with the EU Emissions Trading System. In 2008, we set the most ambitious targets for domestic emissions reductions, renewable energy and energy savings under our 2020 framework. This ambition is paying off. The EU is on track to meet our targets. At the same time, we have seen our economy grow. Since 1990, Europe's greenhouse gas emissions have fallen by $19 \%$, while our GDP rose by $45 \%$. So we prove that climate protection and a strong economy can - and must - go hand-in-hand (Barroso, 2014).

Like the EU, China legitimises its representation as a responsible actor by frequently referencing specific examples of good practice. Beijing habitually stresses that it is leading in terms of green tech innovation. Examples can be found in the annual reports published by the National Development Reform Commission: 'China's current capacity in hydropower, nuclear, solar, and wind power, and plantation areas all rank first in the world, which has made a positive contribution to addressing global climate change' (NDRC, 2013, p. 4). This strengthens China's position as a responsible actor when considered in conjunction with China's identity as a developing economy. Like the EU, China provides not only diplomatic 
leadership in international negotiations but also directional leadership. The emphasis is on technological innovation, reduction of energy consumption and the aim to establish a 'low carbon economy' as illustrated in a speech by the Chinese ambassador at the Conference of the European Technology Platform for Zero Emission Fossil Fuel Power Plans in 2009 (Zhe, 2009). In the 2015 U.S.-China Joint Presidential Statement on Climate Change, China restated its commitment to decrease carbon dioxide emissions per unit of GDP by $60 \%$ to $65 \%$ by 2030 . Specific policy measures that help to reach this target include low carbon pilot projects in selected provinces and cities, a domestic pilot carbon emissions trading programs, low-carbon industrial parks and communities, and low-carbon transport (CCCHINA, 2015e). Apart from the Positive Example Frame, both actors also use specific Evidence Frames to support the positioning of themselves as partners and advocates of the Global South. This is designed to further legitimise the moral positioning as a responsible actor. The EU has long acknowledged the environmental dimension of development issues. Sustainable development has become a key phrase in the EU development discourse with the term being officially anchored within the EU's acquis communautaire. In its press releases on climate change the EU routinely uses specific figures to support its position as partner for developing economies in adjusting to climate change and its challenges. The emphasis is on financial assistance for climate-relevant development assistance. Two extracts from speeches by EC Commissioners in 2012 and 2015 are typical examples how this frame manifests itself:

\footnotetext{
Between 2002 and 2010 the Commission alone provided 3.3 billion euro for climate-relevant projects through traditional official development assistance [...] by 2012, all Pacific ACP countries will have benefited from additional EU funding for climate change, notably with 38.3 million euro (Piebalgs, 2012).
} 
At least 14 billion euros, an average of EUR 2 billion per year of public grants from the EU budget

will support developing countries between 2014 and 2020. This is more than double the average level in 2012-2013. The EU will continue delivering its share of the USD 100 billion per year by 2020 for climate action in developing countries (Cañete, 2015a).

Like the EU, China employs the Evidence Frame to substantiate its developing country identity and its position as leader and advocate of the Global South in global climate change negotiations. China has historically positioned itself as representative of the G77 (a group of 134 developing countries). Evidence is offered in the yearly updates entitled China's Policies and Action on Climate Change released by the National Reform and Development Commission (NRDC). Its size enables China to take on a leadership role while being part of a wider coalition offers some protection against being single out for its emission records.

\section{F4 - Relationship to Others}

Identities do not exist as some form of an independent reality, waiting to be discovered. The 'self' is actively constructed through processes of social interaction, pointing to the constitutive role of discourse and narratives (Davis \& Harré, 1990). Indeed, positioning makes the conceptualisation of the 'other' an integral part of identity construction. Othering can be negative, projecting negative attributes and chiding other groups and actors, or positive, projecting the image of the 'self' alongside important 'others'. Both, positive and negative othering have played a role in the construction of the NFPA image. With Negative Othering Frames the 'self' of the EU, for example, is depicted in a positive light in contrast to negative 'others'. This does not only create an image of the EU as a morally responsible climate change actor (in contrast to the 'others'), it substantiates the notion of the EU as an actor in the first place. For example, the EU is pitched against the US or China, criticising 
those 'others' for not doing enough or being obstacles in the way of a more enlightened climate change regime. Between 2008 and 2013 the dominant othering frame emphasized that the EU was ready to reach a legally binding agreement. However, as Connie Hedegaard, Commissioner for Climate Action, bemoaned during a public lecture in 2010, 'other key players are not' (Hedegaard, 2010b). The US (and China) were portrayed as major impediments for the provision of global public goods in the form of effective environmental governance (Hedegaard, 2010b). This frame was repeatedly used between 2008 and 2013. Examples can be found in a speech by Hedegaard and a press release by the Commission in preparation of the COP17 in 2011. In both documents, the need for collective action is emphasised:

what is the point in making the bridge to the future if nobody will follow us into that future? [...]

Europe is ready [...] Europe is not the problem (Hedegaard, 2011).

a second Kyoto period with only the EU, representing $11 \%$ of global emissions, is clearly not enough for the climate (EC, 2011).

Since 2013, this has been increasingly been replaced by Positive Othering Frames, reflecting developments within the US and China that are regarded as 'positive signals' (EC, 2013). The European Commission has repeatedly appealed to step up efforts to deal with climate change. By doing so and by commending the efforts of other major players, the notion of the EU as an important global actor is being reinforced. A key example of this can be found in a 2015 press briefing by the Commissioner for Climate Action and Energy Union:

The good news is that, after a slow start, more and more countries are submitting their contributions: so far, 56 countries representing $61 \%$ of current global emissions. 
[...] The contributions have not just come from the biggest emitters - including China, the United States and the European Union - but also from some of the most vulnerable countries in Africa, the Caribbean and the Pacific (Cañete, 2015b).

This supports the positioning of the EU as a diplomatic leader in climate change negotiations. China too uses othering frames to cement its own position as a legitimate actor in climate change relations. Frequently mentioned key metaphors include differentiated responsibilities and respective capabilities. Indeed, the Differentiated Responsibilities Frame is the dominant othering frame employed by China. China underlines not only its identity as a developing country but also shifts responsibility for climate change action to the developed world. Xie Zhenhua, for example, stated during the 2008 UNFCCC that:

[...] developed countries should take the lead in reducing their GHG emissions, strictly fulfil their emission reduction commitments under the Kyoto Protocol for the first commitment period, and make further deep cuts to their greenhouse gas emissions by at least $25-40 \%$ below 1990 level by 2020. Meanwhile, developed countries should also fulfil their commitments under the Convention and its Kyoto Protocol supporting developing countries with financial resources, capacity building and the transfer of technology (Zhenhua, 2008b).

In other words, developed countries (i.e. the 'other') ought to shoulder the main burden in the fight against climate change (CCCHINA, 2015c). Developing countries such as China are at different stages of development. Wen Jiabao illustrates that by arguing that although his country is:

$[\ldots]$ in the stage of fast industrialization, its per capita greenhouse gas emission is less than one third that of developed countries and its total historical per capita emission level is even lower. Moreover, a considerable portion of its total emission comes from subsistence emission needed to guarantee people's livelihood and transferred emission from international manufactures. We are 
under multiple pressures to grow the economy, eliminate poverty and slow down greenhouse gas emission (Jiabao, 2008).

This frame is routinely used to support the Partner and Advocate of the Global South Frame. In the same speech Wen Jiabao evokes the principle of differentiated responsibilities before directly appealing, on behalf of developing countries, to developed countries to meet their differentiated obligations (Jiabao, 2008). Clearly then, China is using developed countries as the significant other to cement its positioning as a leader and advocate of the Global South. Another example of this can be found in the Joint Statement issued at the conclusion of the $13^{\text {th }}$ BASIC meeting on Climate Change in November 2012. Here, the parties note with 'consternation that the mitigation contribution by developing country Parties is much greater than that by developed country Parties' and object to attempts 'to transfer to developing countries the commitments and obligations of developed countries' (NDRC, 2012). This is an open criticism of the Global North as a major break pad in climate change management, simultaneously positioning China as speaker on behalf of the Global South.

\section{Conclusions}

This article has analysed the positioning of the EU and China as NFPA in global climate change negotiations. The background for this investigation is the general literature on actorness, more specifically on normative actorness. While there have some notable scholarly developments in the field in recent years there has been little systematic investigation how such general normative actorness is generated. The article proposes to fill this gap by approaching NFPA as a carefully constructed image/ identity, thereby ascribing agency to the

builders of such images. The main point of interest is how external recognition as a normative actor may be constructed and maintained. Accordingly, international actors construct the 
NFPA image in three steps: they (morally) evaluate an issue; take position by aligning themselves; and locate the 'other' to reflect (positively) on the 'self'. Positional framing analysis offers interesting insights into the communicative strategies employed by the EU and China in the construction of the NFPA image.

Several distinct frames that support the evaluation of climate change as a challenge or risk have been detected. Nascent actors and emerging powers, such as the EU and China, aim to gain recognition and establish themselves by differentiation, i.e. as a different kind of power and a force for collective good. This legitimises the positioning of the EU and China as responsible actors and diplomatic leaders which in turn is supported with specific evidence. The construction of the other also plays an important role. While the generic frames are very similar, the EU and China employ very different strategies and construct very different NFPA images of themselves. The EU is striving for a stronger international profile in the climate change discourse. This is confirmed by the repeated emphasis on diplomatic leadership, ambitious targets and the support for developing countries. Indeed, the responsible actor and leading by example frames (directional leadership) are frequently employed. Additionally, the EU has employed negative and positive othering frames to position itself in relation to other actors. Presenting the US or China as obstacles was frequent between 2008 and 2013 but has since been replaced by endorsement of the actions of those two and other major countries. This is in part a reflection of the progress that has been achieved.

China makes significantly more use of negative othering than the EU. The differentiated responsibilities frame is dominant here. This is in line with China's identity as a major developing country, speaking on behalf of developing countries who are exposed to climate change and are much less able to respond to the various challenges. China espouses the view that it is a historical responsibility of developed countries to carry the main burden and do more to facilitate the adaptation of developing countries. One interpretation of the continuous 
use of this framing device by China is that Beijing has only recently emerged as a major actor in global climate change governance. China is using the normative actor image to legitimise itself as a rising power, to delineate itself from other actors and to gain support from other developing countries. It is part of the 'leader of the developing world' discourse. China has also been relatively consistent in its scepticism of internationally binding emission reduction commitments which is in line with its general stance on sovereignty and suspicions of external interference.

The findings suggest a long-term consistency in the communicative strategies employed by the EU and China. Further research is needed on the actual impact, i.e. whether the EU and China are actually regarded as NPFAs in climate change negotiations. It would also be interesting to see, how the NPFA is being constructed by other actors, in other contexts.

\section{References}

Andreouli, E., 2010. Identity, Positioning and Self-Other Relations. Papers on Social Representations, Volume 19, pp. 14.1-14.13.

Barroso, J., 2014. Speech by President Barroso at the Climate Summit 2014. [Online] Available at: http://europa.eu/rapid [Accessed 77 2018].

Boulding, K., 1956. The Image: Knowledge in Life and Society. Ann Arbor: University of Michigan Press.

Breslin, S., 2013. China and the global order: signalling threat or friendship?. International Affairs, 89(3), pp. 615-34.

Bretherton, C. \& Vogler, J., 2006. The European Union as a Global Actor. London: Routledge. Bull, H., 1982. Civilian Power Europe: A Contradiction in Terms?. Journal of Contemporary Market Studies, 21(2), pp. 149-170.

Cañete, M., 2015a. Speaking points by Climate Action and Energy Commissioner Miguel Arias Cañete at the press conference preceeding the COP21 Climate Change Conference in Paris. [Online] Available at: http://europa.eu/rapid

[Accessed 77 2018]. 
Cañete, M., 2015b. EU Press Briefing. [Online]

Available at: http://europa.eu/rapid

[Accessed 107 2018].

CCChina, 2013. Joint China-U.S. Statement on Climate Change. [Online]

Available at: http://en.ccchina.org.cn/

[Accessed 20 April 2018].

CCCHINA, 2015b. U.S.-China Joint Presidential Statement on Climate Change. [Online]

Available at: http://en.ccchina.org.cn

[Accessed 47 2018].

CCCHINA, 2015c. Joint Statement on Climate Change between the Government of the People's Republic of China and the Government of the Republic of India. [Online]

Available at: http://en.ccchina.org.cn/

[Accessed 107 2018].

CCCHINA, 2015d. 20th BASIC Ministerial Meeting on Climate Change - Joint Statement. [Online] Available at: $\underline{\text { http://en.ccchina.org.cn }}$

[Accessed 107 2018].

CCCHINA, 2015e. U.S.-China Joint Presidential Statement on Climate Change. [Online]

Available at: http://en.ccchina.org.cn

[Accessed 97 2018].

Chin, G., 2010. China's Rising Institutional Influence. In: A. Cooper \& A. Alexandroff, eds. Rising States, Rising Institutions: Challenges for Global Governance. Baltimore: Brookings Institution Press, pp. 83-104.

Chong, D. \& Druckman, J., 2007. Framing Theory. Annual Review of Political Science, Volume 10, pp. 103-26.

Cui, T., 2013. Beijing's Brand Ambassador: a conversation with Cui Tianka. Roreign Affairs, 92(4), pp. 10-17.

Davis, B. \& Harré, R., 1990. Positioning: the discursive production of slef. Journal for the Theory of Social Behaviour, Volume 20, pp. 43-63.

Diez, T., 2005. Constructing the Self and Changing Others: Reconsidering 'Normative Power Europe'. Millennium Journal of International Studies, 33(3), pp. 615-36.

Diez, T. \& Pace, M., 2007. Normative Power Europe and Conflict Transformation. [Online] Available at: http://aei.pitt.edu/7798/1/diez-t-01a.pdf

[Accessed 6 June 2016].

Du Bois, J., 2007. The stance triangle. In: R. Englebretson, ed. Stancetaking in Discourse: Subjectivity, Evaluation, Interaction. Amsterdam: John Benjamins, pp. 139-82. 
Duchêne, F., 1972. Europe's Role in World Peace. In: R. Mayne, ed. Europe Tomorrow, Sixteen Europeans Look Ahead. London: Collins Publishers, pp. 32-47.

Duveen, G., 1993. The developemtn of social representations of gender. Papers of Social Representations, 2(3), pp. 171-77.

EC, 2009. Commission welcomes adoption of climate and energy package, Press Release, IP/09/628. [Online]

Available at: http://europa.eu/rapid

[Accessed 17 May 2019].

EC, 2009. Copenhagen conference must produce global, ambitious and comprehensive agreement to avert dangerous climate change, Press Release, IP/09/1867. [Online]

Available at: http://europa.eu/rapid

[Accessed 17 May 2019].

EC, 2009. Statement of President Barroso to the Plenary of the Copenhagen conference on climate change, Speech/09/587. [Online]

Available at: http://europa.eu/rapid

[Accessed 23 April 2018].

EC, 2011. Durban must deliver a roadmap for climate action by all major economies, Press release, IP/11/1436. [Online]

Available at: http://europa.eu/rapid

[Accessed 23 April 2018].

EC, 2011. Durban must deliver a roadmap for climate action by all major economies, Press release, IP/11/1436. [Online]

Available at: http://europa.eu/rapid

[Accessed 23 April 2018].

EC, 2012. Pacific Islands - EU relations: Focus on Climate change. [Online]

Available at: http://europa.eu/rapid

[Accessed 20 April 2018].

EC, 2013. Statement by President Barroso and Climate Action Commissioner Connie Hedegaard on President Obama's Climate Action Plan, Memo/13/612. [Online]

Available at: http://europa.eu/rapid

[Accessed 15 May 2018].

EC, 2014c. EU-Africa Ministerial Statement on Climate Change. [Online]

Available at: http://europa.eu/rapid

[Accessed 20 April 2018].

EC, 2014d. Statement by President Barroso at the joint press conference on climate and energy with United Nations Secretary General Ban Ki-moon and World Bank President Jim Yong Kim;

Speech/14/56. [Online] 
Available at: http://europa.eu/rapid

[Accessed 23 April 2018].

EC, 2015a. Speech by Commissioner Miguel Arias Cañete at the 46th Pacific Islands Forum Plenary Session; Speech/15/5613. [Online]

Available at: http://europa.eu/rapid

[Accessed 23 April 2018].

EC, 2015b. Questions and Answers on the European Commission Communication: The Paris Protocol - A blueprint for tackling global climate change beyond 2020 - MEMO/15/4487. [Online]

Available at: http://europa.eu/rapid

[Accessed 14 April 2018].

Entman, R., 2004. Projections of power: Framing news, public opinion, and U.S foreign policy.

Chicago: University of Chicago Press.

Galtung, J., 1973. The European Community - A Superpower in the Making. London: Allen and Unwin.

Gordon, C., 2015. Framing and Positioning. In: D. Tannen, H. Hamilton \& D. Schiffrin, eds. The Handbook of Discurse Analysis. Chichester: John Wiley and Sons, pp. 324-45.

Harré, R. \& Van Langenhove, L., 1999. Positioning Theory. Oxford: Blackwell.

Hedegaard, C., 2010a. Enhancing the interrelationship between climate change, biodivestity and desertification for sustainable development. [Online]

Available at: http://europa.eu/rapid

[Accessed 47 2018].

Hedegaard, C., 2010b. Europe's view on International Climate Policy. [Online]

Available at: http://europa.eu/rapid

[Accessed 107 2018].

Hedegaard, C., 2011. Preparation of the Climate Change Conference (COP17) in Durban. [Online] Available at: http://europa.eu/rapid

[Accessed 107 2018].

Jiabao, W., 2008. Strengthen International Technology Cooperation and Address Climate Change Actively. [Online]

Available at: $\underline{\text { http://en.ccchina.org.cn/ }}$

[Accessed 16 April 2017].

Jintao, H., 2008. Remarks at the Major Economies Meeting On Energy Security and Climate Change.

[Online]

Available at: http://www.fmprc.gov.cn

[Accessed 47 2018].

Jintao, H., 2009. Join Hands to Address Climate Challenge. [Online]

Available at: http://en.ccchina.org.cn/

[Accessed 47 2018]. 
Kavalski, E., 2007. Partnership or Rivalry between the EU, China and India in Central Asia: The Normative Power of Regional Actors with Global Aspirations. European Law Journal, 13(6), p. 83956.

Kavalski, E., 2013. The Sruggle for Recognition of Normative Powers: Normative Power Europe and Normative Power China in Context. Cooperation and Conflict, 48(2), pp. 247-67.

Kavalski, E., 2014. The Shadows of Normative Power in Asia: Framing the International Agency of China, India, and Japan. Pacific Focus, 29(3), pp. 303-28.

Kelemen, R., 2010. Globalizing European Union Environmental Policy. Journal of European Public Policy, 17(3).

Lavenex, S., 2004. EU external governance in 'wider Europe'. Journal of European Public Policy, 11(4), pp. 680-700.

Lindekilde, L., 2014. Discourse and Frame Analysis. In-Depth Analysis of Qualitative Data in Social Movement Research. In: D. Porta, ed. Methodological Practices in Social Movement Research. Oxford: Oxford University Press, pp. 195-227.

Manners, I., 2002. Normative Power Europe: A Contradiction in Terms?. Journal of Common Market Studies, 40(2), pp. 235-58.

Manners, I., 2006. The symbolic manifestation of the EU's normative role in world politics. In: O. Elgström, ed. The European Union's Roles in International Politics - Concepts and Analysis. London: Routledge, pp. 66-84.

Manners, I., 2010. Global Europa: Mythology of the European Union in World Politics. Journal of Contemporary European Studies, 48(1), pp. 67-87.

Manners, I. \& Whitman, R., 2003. The 'difference engine': constructing and representing the international identity of the European Union. Journal of European Public Policy, 10(3), pp. 380-404.

Mearsheimer, J., 2006. China's Unpeaceful Rise. Current History, 105(690), pp. 160-62.

Mohanty, M., 2013. Xi Jinping and the 'Chinese Dream'. Economic \& Political Weekly, XJVIII (38), pp. $34-40$.

NDRC, 2012. Joint Statement Issued at the Conclusion of the 13th BASIC Ministerial Meeting on Climate Change. [Online]

Available at: $\underline{\text { http://en.ccchina.org.cn/ }}$

[Accessed 107 2018].

NDRC, 2013. China's Policies and Actions for Addressing Climate Change. [Online]

Available at: http://en.ccchina.org.cn

[Accessed 97 2018].

NDRC, 2014. China's Policies and Actions on Climate Change. [Online]

Available at: http://en.ccchina.org.cn

[Accessed 47 2018]. 
NRDC, 2015. China's Policies and Actions on Climate Change. [Online]

Available at: http://en.ccchina.org.cn/

[Accessed 47 2018].

Parker, C. \& Karlsson, C., 2010. Climate Change an the European Union's Leadership Moment: An Inconvinient Truth?. Journal of Common Market Studies, 48(4), pp. 923-43.

Ping, Z., 2008. Technology Development and Technology Transfer. [Online]

Available at: http://en.ccchina.org.cn/

[Accessed 47 2018].

Saarikoski, H., 2006. When Frames Conflict: Policy Dialogue on Waste. Environment and Planning C: Government and Policy, Volume 24, pp. 615-30.

SCPRC, 2011. China's Policies and Actions for Addressing Climate Change. [Online] Available at: http://english.gov.cn

[Accessed 47 2018].

She, Z., 2010. Taking A Positive and Responsible Attitude and Joining Hands to Tackle Climate Change, Speech By H.E. Ambassador Song Zhe. [Online]

Available at: http://en.ccchina.org.cn/

[Accessed 29 April 2018].

Stubbs, R., 2008. The ASEAN Alternative? Ideas, Institutions and the Challenge of "Global" Governance. Pacific Affairs, 21(4), pp. 451-68.

TEU, 2012. Consolidated Version of the Treaty on European Union, s.I.: Official Journal of the European Union, C 326/13.

Tocci, N., 2008. Proliferating normative foreign policy: the European Union and its global partners. In: N. Tocci, ed. Who is a Normative Foreign Policy Actor? The European Union and its Global Partners. Brussels: CEPS, pp. 1-23.

Van Gorp, B. \& Vercruysse, T., 2012. Frames and counter-frames giving meaning to dementia: A framing analysis of media content. Social Science \& Medicine, Volume 70, pp. 1274-1281.

Womack, B., 2008. China as a Normative Foreign Policy Actor. In: Who is a Normative Foreign Policy Actor? The European Community and its Global Partners. Brussels: Centre for European Policy Studies, p. 265-99.

Zhenhua, X., 2008a. Opening Remarks at the Press Conference for the White Paper on China's Policies and Actions on Addressing Climate Change. [Online]

Available at: http://en.ccchina.org.cn/

[Accessed 47 2018].

Zhenhua, X., 2008b. Statement by Mr. XIE Zhenhua at the joint High-Level Segment of COP14 and CMP4. [Online]

Available at: http://en.ccchina.org.cn/

[Accessed 107 2018]. 
Zhe, S., 2010. Taking A Positive and Responsible Attitude and Joining Hands to Tackle Climate Change. [Online]

Available at: http://www.fmprc.gov.cn

[Accessed 47 2018]. 